\title{
Moral Education and the Curriculum: the Ghanaian Experience
}

\author{
Seth Asare-Danso (PhD) \\ Department of Arts Education, \\ Faculty of Humanities and Social Sciences Education, \\ College of Education Studies \\ University of Cape Coast, \\ Cape Coast, Ghana
}

\begin{abstract}
Moral Education is provided by major institutions within the civil society. The social institutions include the family, religious bodies, the mass media and the school. This paper examined the nature of Moral Education that has been provided in the Ghanaian basic schools during the pre-colonial period (1820 up to 1850), the colonial period (1851-1956) and the post-colonial period (1957-2017). A theoretical framework was provided for the study based on three approaches to moral education, namely: Indoctrinative approach, Romanticist approach and Cognitive-Structural approach. A content analysis of educational policy documents and interviews were used for the collection of data. The findings of the research revealed that one of the colonial policies that promoted Moral Education in Ghana was the teaching of morality in public schools based on Christianity, using the Indoctrinative approach. However, this religious approach to morality changed to secular approach during the post-colonial period in Ghana, due to the pluralistic nature of the Ghanaian society. This led to the introduction of "Moral Teaching", "Civics" and later "Citizenship Education". The study welcomed the current policy of separating Religious Education from Moral Education by introducing the teaching of "Civic and Moral Education" and "Religious Studies" at the Colleges of Education, as proposed by the National Council for Tertiary Education. It finally recommended that the Department of Arts Education of the University of Cape Coast began to train teachers who will teach these two courses at the Colleges of Education level. This will equip the teacher trainees with the pedagogical knowledge and skills required for the effective implementation of this new Moral Education programme in Ghanaian basic schools.
\end{abstract}

Key words: Moral Education, Civic Education, Citizenship Education, Traditional African Education, Religious and Moral Education.

\section{Introduction}

Moral Education as a subject has been explored extensively by researchers globally over the years (Piaget, 1965; Kohlberg, 1969; Kohlberg \& Turiel, 1971; Gilligan, 1982; Turiel, 1983). The subject has been given prominence as a result of media reports of increased violence, armed robbery, teenage pregnancy, and suicide, just to mention a few. Regrettably, only a few scholars have researched into the teaching of Moral Education in Africa (Nduka, 1980; Nyabul, 2009; Dinama, 2012; Njoroge, 2012). In the case of Ghana, there is not a single study that has been done specifically on Moral Education. What has been done so far covered Religious and Moral Education (RME), under which Moral Education was treated as an appendix to the study (Asare-Danso, 2012a, Asare-Danso, 2012b). The purpose of this study is to examine the kind of Moral Education that has been provided in Ghanaian basic schools in the past and at present. This is a historical study, and its scope covers the pre-colonial, colonial and post-colonial periods in Ghana (from 1850 to 2017). A Theoretical Framework has been provided for the study. The rest of the study is organized along three research questions as follows: (i) What kind of Moral Education was provided in Ghana during the pre-colonial period? (ii) What kind of Moral Education was provided in Ghanaian basic schools during 
the colonial period? and (iii) What kind of Moral Education was provided in Ghanaian basic schools during the post-colonial period?

\section{Theoretical Framework}

Three different approaches were identified in dealing with moral issues (Kohlberg \& Mayer, 1972). These were the Indoctrinative approach (Wynne \& Ryan, 1993), the Romanticist approach (Raths, Harmin \& Simon, 1966), and the Cognitive-structural approach (Power, Higgins \& Kohlberg, 1989). According to these scholars, the Indoctrinative approach embraces the teaching of a prescribed set of values, which serve as the core of the curriculum. The Romanticist approach does not encourage the provision of a prescribed set of values and as a result, advocates moral relativism. The Cognitive-structural approach advocates the use of reasoning and decision-making processes to determine what is morally good or bad.

Even though all the three approaches to moral education have their defects (Kohlberg \& Mayer, 1972), the Indoctrinative approach seemed to be most appropriate for the Ghanaian classroom situation because of its advocate for specific content in the curriculum. The other two approaches are relativistic in nature. As a result, the Indoctrinative approach has been used in teaching Moral Education to Ghanaian children during the pre-colonial and colonial periods. However, in the post-colonial period, there has been a shift of focus from the Indoctrinative Approach to the Romanticist approach and the Cognitive-structural approach to the teaching of Moral Education. These have provided theoretical framework for the study.

\section{Moral Education in Ghana during the Pre-Colonial Period (1820-1850)}

The study of Moral Education in Ghana could be traced to the pre-colonial period (from 1820 up to 1850) when the subject formed an integral part of Traditional African Education. Before the advent of Western Education, the people of Africa in general and the Gold Coast (now Ghana) in particular had their own indigenous or traditional form of Education. Many scholars have written extensively about Traditional African Education in the past. They include Kenyatta (1965), Mbiti (1969), Ocitti (1973), Fafunwa (1974), Boateng (1983, pp. 321-336), and Kalusa (2000, pp. 24-31).

Traditional African Education was meant to attain the following goals:

i. To develop the child's latent physical skills.

ii. To develop character.

iii. To inculcate respect for elders and those in position of authority.

iv. To develop intellectual skills.

v. To acquire specific vocational training and to develop a healthy attitude towards honest labour.

vi. To develop a sense of belonging and to participate actively in family and community affairs.

vii. To understand, appreciate and promote the cultural heritage of the community at large (Fafunwa, 1974, p. 20).

Education generally aims at the development of the cognitive, affective and the psychomotor domains of the learner. In other words, it aims at the total development of the individual. Therefore, all the above-stated goals satisfy the three domains of educational objectives, as categorized by Bloom (1956), namely cognitive, affective and psychomotor. Traditional African Education aimed at initiating young ones and ushering them into adulthood, to lead very responsible lives in their communities.

One major characteristic of Traditional African Education was that it was not school-based. It was the informal type of education which took place in the home. Parents and adults in the community served as teachers. The adults or elders of the community complemented the efforts of the parents by teaching, scolding, advising, rewarding and punishing children in the community (Blackmore \& Coosey, 1980). Unlike their counterparts in the Formal Educational system, these teachers were not remunerated. However, they were adequately motivated to render this kind of service because the parents showed their appreciation to them for helping with the upbringing of their children. The task of teaching and bringing up children was therefore a collective responsibility of all members of the community.

In pre-colonial Education, there was a clear-cut distinction between pupils and teachers (Data, 1984). The parents and adults in the community who assumed the position of teachers always gave "instruction" to the 
children to obey. "Instruction" requires giving a command for somebody to obey. This did not promote a very good interaction because it made the flow of information always directed from the teacher to the learner. This is different from "Education" which allows the free flow of information from the teacher to the learner and vice versa (Ozigi and Canham, 1979, p. 11).

The curriculum for Traditional African Education covered the things in the social environment. Children were made to learn about how to build good social relationships. This could be done using appropriate greetings and responses; how to show appreciation to people; how to show respect for elders and people in authority; and how to subordinate individual interests to societal interest (Occiti, 1973). All these helped to promote Moral Education among children in Ghana during the pre-colonial period before the advent of formal education.

Besides, the curriculum of Traditional African Education covered issues relating to the spiritual environment. In view of this, the curriculum gave room for the study of Religion. During the pre-colonial times, rites of passage like outdooring of a child or naming ceremony, puberty rites, marriage rites and death rites were all accorded spiritual significance and for that matter, were marked with religious rituals. Besides, events like sicknesses, flood and drought were accorded spiritual significance and purification rites accompanied them. Through songs, proverbs, folktales and myths, children acquired knowledge about the Supreme Being, Ancestors and deities. For example, adults taught children myths, which gave them some ideas about the nature of the Supreme Being. One of these oral stories which I heard from my grandparents in the late 1960's was about how the Supreme Being used to be very close to humans but an old woman who liked pounding "fufu" disturbed him by hitting him with her pestle persistently. ("Fufu" is a traditional Ghanaian dish made up of pounded cassava and cocoyam, yam or plantain, and served with soup and meat or fish). The Supreme Being therefore decided to withdraw to the sky, a place far from human habitation. To teach the young ones Moral Education, the traditional people used such stories. Moral Education therefore played a key role in the life of children and adults in traditional African communities.

Both theoretical and practical methods were employed in teaching traditional African Education. Individuals were made to acquire knowledge, skills and moral competencies through their participation in initiation rites, observation and repetition of certain activities that were performed by adults. Besides, they learned through demonstration, riddles, songs, story-telling, proverbs, folktales, puzzles, tongue twisters, music and dance.

Moral Education in Africa was based on sound philosophical principles. Some of these principles were clearly outlined by Ocitti (1973) as preparationism, functionalism, communalism, perennialism and holisticism.

The principle of preparationism meant that the type of Moral Education that would be given to the individual should be able to fully equip him or her with the knowledge, skills and moral competencies that would enable the learner to perform certain key roles in order to fulfill certain societal responsibilities. This kind of education was gender-based. Therefore, the males were educated to acquire male-dominated occupations to become farmers, fishermen, blacksmiths, warriors and rulers. In the case of the females, they were educated to become future wives, mothers and housekeepers. One advantage of this traditional type of education is that it prepared the members to appreciate the history, language, customs, traditions and values of the community. One way of achieving this was to allow young people to go through initiation rites. Taking girls' nubility rites as an example, the girls may have their hair shaved; they are quarantined and given sex and family life education. After one week, when they are outdoored, they receive many presents. They then have to show their appreciation by going round to thank all those who gave them presents. This traditional ritual therefore prepares girls for life. Boys may also have their initiation rites, which are performed on them, and they all aim at preparing them to lead adult life.

The second point is that Moral Education was based on the philosophical principle of functionalism or utilitarianism. People were made to acquire knowledge and skills, which would enable them to render useful services to their communities and to the larger society. There was nothing like rural-urban migration, as we are experiencing in Ghana today.

Thirdly, the teaching of Moral Education was based on the philosophical principle of communalism. By this principle, people were made to think not only of their welfare but to seek the welfare of others as well. Group work was emphasized and members applied this spirit of communalism to life and work. Under the 
spirit of communalism, any adult person in the community could discipline any child who misbehaves, in the absence of the parents. The reason is that any calamity that befalls a child affects the whole community. Similarly, Moral Education in pre-colonial Ghana was characterized by the principle of perennialism. What this meant is that Education was meant to equip the individual with the knowledge, skills and attitudes that would enable him or her to get a life-long vocation in order to preserve the cultural heritage of the people. If one practices farming or fishing as a vocation, one carries it along until his or her death. The issue of unemployment was therefore unknown in traditional African culture prior to the introduction of western education.

The fifth philosophical principle of Moral Education was that it was holistic. Its holistic nature encouraged multiple learning. This enabled the individual to acquire a variety of knowledge and skills that would make the individual more functional and productive. In this case, a woman may be encouraged to work as a wife, mother, housewife, cook, caretaker and a nurse to her family. In the same way, a man may work as a husband, farmer, fisherman and a builder, as the case may be.

Even though Moral Education in pre-colonial Ghana was not structured, with the support of all adults in the whole community, it was able to help in molding the character of the young ones to grow up to become responsible adults in the society. Besides, it helped in promoting peaceful co-existence among members of the community (Okoro, 2010; Katola, 2014). The content of the curriculum of traditional African Education was able to prepare learners to develop skills in physical fitness, moral uprightness, coping with religious differences, good social adjustment and social interaction (Okoro, 2010, p. 144). Even though religious morality was the preferred choice of the African people during the pre-colonial times, it was able to serve its purpose of inculcating in the young ones good moral values. Now, let us examine the nature of Moral Education in Ghana during the colonial era.

\section{Moral Education in Ghana during the Colonial Period (1851-1956)}

During the colonial era (1851-1956), Moral Education continued to be provided for the people of Ghana. This time, the school took over the teaching of the subject from the home. Certain colonial educational policies affected the teaching of Moral Education in Ghanaian basic schools during the colonial era.

The colonial governments (Portuguese, Dutch and the Danes) used the castles that were serving as trading posts for the establishment of the Castle Schools at Elmina, Cape Coast and the Christiansborg, Osu (McWilliam \& Kwamena-Poh, 1975, pp.17-20; Graham, 1976, pp.1-7). During the colonial era, the religious morality was enforced and this led to the use of the Indoctrinative approach in teaching Moral Education. In the school curriculum, Religious Instruction was used to teach Moral Education, and the content was exclusively based on Christianity. Bible passages were used to indoctrinate pupils (Wise, 1956, p.9).

The Basel Mission followed this pioneering role by the European merchants by establishing their first schools at the Christiansborg, Osu in 1828, Akropong in 1843 and Aburi in 1847 (Odamtten, 1978). Religious Instruction was part of the school curriculum, and it was used to teach Moral Education to children (McWilliam \& Kwamena-Poh, 1975, p.19).

The colonial government also adopted the Basel Mission educational policy (McWilliam \& Kwamena-Poh, 1975; Graham, 1976) and encouraged the teaching of Moral Education in Ghana. For example, under Governor Guggisberg, he outlined Sixteen Principles of Education, which was presented to the Legislative Council of the then Gold Coast for approval in 1925. The $7^{\text {th }}$ principle stated: "Character training must take an important place in education" and the $8^{\text {th }}$ principle stated: "Religious teaching should form part of school life" (McWilliam \& Kwamena-Poh, 1975, p.57). The $7^{\text {th }}$ Principle of Education therefore promoted the teaching of Moral Education, whereas the $8^{\text {th }}$ Principle of Education also tried to promote the teaching of Religious Education.

The teaching of Moral Education continued to be encouraged in Ghanaian educational system during the Nationalist period (from 1951 to 1966). Under Dr. Kwame Nkrumah's "Accelerated Development Plan" policy of 1952 when he was made the Leader of Government Business, Religion was used to teach Moral Education. The subject was given the title Religious Instruction (MOE Report, 1957, p.8), and it had pedagogic implication. What it meant was that children were given instruction on moral issues, and as a result, the Indoctrinative approach was used in promoting Moral Education at the time.

Moral Education in Ghana during the Post-Colonial Period (1957-2017) 
Let us also examine policies that post-independence governments (1957-2016) put in place to promote Moral Education in Ghanaian basic schools. After the attainment of political independence in Ghana in 1957, President Nkrumah's Government proposed to introduce "Moral Teaching” in place of "Religious Knowledge" in the Basic School curriculum in 1962.

With the introduction of "Moral Teaching" as a subject, President Nkrumah wanted to encourage secular morality, rather than religious morality. To implement his educational policy, he formed an association known as the "Ghana Young Pioneer Movement. Membership was opened to all young people in Ghana, both male and female. The Movement was formed in all basic schools in Ghana, and Headteachers were to help with the implementation of this new educational policy.

The Young Pioneer Movement was meant to perform the following functions:

(1) To train the mind, the body and the soul of the youth of Ghana.

(2) To train them to be up to their civic responsibilities so as to fulfill their patriotic duties.

(3) To train their technical skills, according to their talents.

(4) To foster the spirit of voluntarism, love and devotion to the welfare of the Ghana nation.

(5) To inculcate into the youth "Nkrumaism" - ideals of African personality, world peace, social and economic reconstruction of Ghana and Africa in particular, and the world in general (PRAAD, 1961; Asare-Danso, 2012a).

Under Nkrumah's new Moral Education programme, young people in Ghana were made to complete membership forms for their parents to endorse. They were then made to take the Young Pioneer Movement Oath, saying:

1. I sincerely promise to live by the ideals of Osagyefo Dr. Kwame Nkrumah.

2. To safeguard by all means possible the independence sovereignty and territorial integrity of the state of Ghana from internal and external aggression.

3. To be always in the vanguard for the social and economic reconstruction of Ghana and Africa.

4. To be in the first batch of men fighting for the total liberation and unity of Africa, for these are the noble aims guiding the Ghana Young Pioneers.

5. As a young pioneer, I will be a guard of workers, farmers, co-operators and all the sections of our community.

6. I believe that the dynamic CPP is always supreme, and I promise to be worthy of its ideals (PRAAD, 1961; Asare-Danso, 2012a).

The Young Pioneer Movement was inaugurated at Teshie in Accra in November 1960 as a youth movement. By 1961, the National Youth Council had been dissolved and replaced with the Young Pioneer Movement. The Movement was then placed directly under the Ministry of Education in Ghana. Branches were established in all regions and districts in Ghana, and also in schools, including the mission schools.

According to an informant who was interviewed, the activities of the Young Pioneer Movement affected the management of mission schools in particular, in the sense that some teachers were withdrawn from the schools and trained as Commissioners of the Movement, after going through a period of training at Kwame Nkrumah Training College, Teshie in Accra. The informant added that later, the training session was moved from Teshie in Accra to the Kwame Nkrumah Ideological Institute at Winneba, which has now become a campus of the University of Education, Winneba.

This new Moral Education programme created a lot of problems for the nation. First, part of the instructional time to be used for teaching and learning in the schools was used to train some boys and girls who registered for the Young Pioneer Movement.

Secondly, some teachers were seconded to the Young Pioneer Movement, and they created vacancies in their schools. For example, according to an informant, at Dunkwa District, two teachers of the Presbyterian Middle School, namely Asiedu Offei and J. K. Boateng were seconded to the Young Pioneer Movement so they had to leave their classes behind.

Besides, the children were made to pledge to live by the ideals of Osagyefo Dr. Kwame Nkrumah, as Oath No. 1 of the Young Pioneer Movement has suggested above. Morally, I think that asking the children to pledge to live by the ideals of Osagyefo Dr. Kwame Nkrumah amounted to giving them a new morality (secular morality), which was different from the type that the colonial government and the mission schools 
tried to inculcate in the young ones. This was bound to bring political conflict between the government of Ghana and the mission schools, and it really happened. For example, Mr. E. J. Klufio, the Headmaster of the Presbyterian Boys' Secondary School (PRESEC) at Legon had confrontation with the Nkrumah government over the implementation of the programme at PRESEC (Education Report on Presbyterian Boys' Secondary School, Legon, 1964).

The nation also suffered financially, due to the introduction of the new Moral Education programme. For the 1961-1962 financial year, £G 350,000 (Three Hundred and Fifty Thousand Great Britain Pounds) was allocated to the Ministry of Education as subvention to the Ghana Young Pioneer Movement (MOE Report, 1960-62, p.13).

Eventually, this new Moral Education programme could not be successfully implemented because it was vehemently opposed by religious bodies whose schools were affected. For example, when the Rt. Rev. E. M. L. Odjidjah, the Moderator of Synod of the Presbyterian Church of Ghana led the Synod Committee to discuss the issue, the church vehemently opposed this educational policy (Synod Committee Report on "Christian Education - Study and Practice", on 25 - 26 April, 1962, paragraph 1776).

In the 1970's, Moral Education was taught in Ghanaian basic schools under the designation Civics. This curriculum provided for citizenship education. There was a textbook entitled "Civics for Self-Government" that was used for the implementation of this programme. I personally made use of this curriculum during my basic school days, and I remember this curriculum tried to educate pupils among other things, on the characteristics of "Active", "Passive" and "Bad" citizenship, for them to make the right moral choices.

In the 1980's, under the military regime of President Jerry John Rawlings and his Provisional National Defense Council (PNDC) government, Moral Education continued to be taught in Ghanaian basic schools, using the teaching of Religion. At this time, Religion was integrated into a new subject known as Cultural Studies. It was an integration of three subjects, namely: Religion, Culture and Music. This subject was used to teach Moral Education in basic schools in Ghana during this period.

In the 1994, Cultural Studies was removed from the basic school curriculum. Concerns were raised by the public following the removal of Religion from the school curriculum. This caused a National Education Reform Review Committee (NERRC) to be set up in 1994. Based on its recommendations, Religion was reintroduced, under the title Religious \& Moral Education (RME) and a syllabus was developed by the Ministry of Education, Ghana in 1998 for the teaching of the subject.

In 2002, a committee was set up by President J. A. Kuffour to review the educational system in Ghana. It was headed by Professor Jophus Anamuah-Mensah, who was then the Vice Chancellor of the University of Education, Winneba. The Committee proposed that fewer subjects should be taught at the Basic School level and recommended that:

"At the lower level, reading, writing, dictation and comprehension

texts should incorporate concepts of Religious and Moral Education, Culture, Science, Hygiene, Agricultural Science, Life Skills and

Civics and should be taught in an integrated manner" (Meeting the

Challenges of Education in the Twenty First Century, 2002, p.4).

Consequently, Religious and Moral Education was removed from the Basic School curriculum in 2007. The Catholic Bishops' Conference of Ghana described the integration of Religion into other subjects as making Religion "an appendix" to those subjects (Gurney, 2007). In response to these public agitations, President Kuffour used his 2008 May Day Anniversary Speech to instruct authorities of the Ghana Education Service to re-introduce Religious and Moral Education as a subject on its own from the 2008/2009 academic year. The subject therefore continued to be used in teaching Moral Education in Ghanaian basic schools.

Besides, Citizenship Education was introduced at the Lower Primary Level (i.e. Basic 4, 5 \& 6) to teach Moral Education (MOESS, 2007). The syllabus for Citizenship Education was designed to help pupils to:

1. build attitudes and values needed to solve personal and societal problems

2. develop critical thinking skills.

3. develop a sense of national consciousness, unity and development.

4. acquire desired characteristics of a Ghanaian patriot.

5. develop an appreciation for peace and always work towards it (MOESS, 2007). 
In terms of scope, the subject (Citizenship Education) integrates knowledge and information from many subject areas, such as Civics, Hygiene, Social Studies, Life Skills and Religious and Moral Education. Issues such as the promotion of good governance, democracy, sustainable management of environment, peace and human rights have been emphasized. The issues selected are those that are necessary to promote the child's active participation in the public life and community issues in an informed, committed and constructive manner, with a focus on the common good.

With Citizenship Education, the syllabus introduces the child to critical and reflective thinking, decision making, positive attitudes and value building. It also focuses on personal and civic responsibility, as well as, the rights that go with the responsibilities. This suggests a change in focus from the Indoctrinative approach to the Romanticist approach, which avoids the provision of a prescribed set of values and advocates moral relativism, as well as the Cognitive-structural approach, which advocates the use of reasoning and decisionmaking processes to determine what is morally good or bad.

Currently, there is another proposal to separate Moral Education from Religious Education and to teach them as separate subjects at the basic school level. This new policy seeks to introduce the teaching of "Civic and Moral Education" in addition to "Religious Studies" at the Colleges of Education level where teachers are prepared to teach at the basic schools. This has been proposed by the National Council for Tertiary Education (NCTE) in the Harmonised Statutes for Colleges of Education (NCTE, 2015, p. 53).

\section{Concluding Remarks}

Moral Education has been provided by major institutions within the civil society, which include the family, religious bodies, the mass media and the school. In the school, the Indoctrinative approach was used in the past, but this has given way to the Romanticist approach, which encouraged moral relativism, and the Cognitive-structural approach, which advocates the use of moral reasoning to determine what is morally good or bad. It is important to note that even though the school is introducing children to the Moral Education Curriculum, it is doing that in partnership with the other social institutions like the home and the media. For example, in the Religious and Moral Education Syllabus, the Rationale for the teaching of the subject indicated that "The subject reinforces the informal religious and moral training that young people acquire from their homes and communities" (Ministry of Education, Science and Sports, 2008).

The study has also revealed a change in focus from religious morality to secular morality, and the separation of Moral Education from Religious Studies. I see the separation of Moral Education from Religious Studies to be a very good idea. The reason is that considering the pluralistic nature of the Ghanaian society, there is a need for a kind of morality that will not be based on a particular religious tradition. When this happens, it will promote social harmony among all interest groups, be it religious, political or social.

The teaching of Moral Education in Ghana has gone through an evolutionary process. It has been taught as part of Religion under the designated titles Religious Instruction, Religious Knowledge, Cultural Studies and Religious and Moral Education. Alternatively, it has also been taught as a subject being separated from religion under the designated titles Moral Teaching, Civics, Citizenship Education, and lastly, Civic and Moral Education, which has been proposed by the National Council for Tertiary Education (NCTE), and it is yet to be implemented.

Again, society is dynamic, and the Ghanaian society is no exception. As a result, the study has revealed that the country (Ghana) has moved away from what I may describe as a stage of "moral dependency" to its current stage of "moral autonomy", as suggested by Piaget (1965). From the pre-colonial era through the colonial era, the country found itself in the stage of "moral dependency". However, from the post-colonial era, there has been a change from the stage of "moral dependency" to the stage of "moral autonomy", and this is very commendable.

Children should be encouraged to develop a sense of "moral autonomy" when they are young. As a result, they need a kind of Moral Education that will challenge them to take moral decisions on their own without any external influence. Piaget's theory of Morality indicates that there is a direct correlation between a child's cognitive abilities and his or her moral judgement. His theory also indicates that one's cognitive abilities and its growth are influenced by one's age category. His theory therefore revealed that from 10 
years and above, children were able to develop "autonomous morality". This is the reason why I think teachers in Ghanaian basic schools should be equipped with appropriate pedagogical knowledge and skills (Asare-Danso, 2017). This will enable them to introduce children to a kind of Moral Education curriculum that will challenge their minds to do moral reasoning (using the Cognitive-structural approach). It will also equip the teachers to help the children to express divergent views on moral issues (using the Romanticist approach).

\section{Recommendations}

The following recommendations have been made to influence educational policy and practice:

1) The teaching of Morality should not be based on Religion, considering the pluralistic nature of society.

2) The efforts being made by the school to implement the Moral Education curriculum should be complemented by the collective efforts of all social institutions like the home, the mass media and religious bodies.

3) Moral Education and Religious Education should be treated as separate subjects in the school curriculum.

4) The Department of Arts Education of the Faculty of Humanities and Social Sciences Education, University of Cape Coast, Ghana, should begin to train teachers who will teach Religious Education and Moral Education as separate subjects at the Colleges of Education level.

5) Teacher trainees at the Colleges of Education in Ghana should be fully equipped with the pedagogical knowledge and skills required for the effective implementation of this new Moral Education curriculum in Ghanaian basic schools.

\section{References}

1. Asare-Danso, S. (2012a). Basel mission education in the Gold Coast / Ghana (1950-2007): Effects of education acts on missionary education. Saarbrucken: Lambert Academic Publishing GmbH\& Co. KG.

2. Asare-Danso, S. (2012b). Religious education in a democratic state: The Ghanaian experience. In P. Gotke, \& J. Nissen (Eds.), Religious education between formation, knowledgeand control, (pp. 59-65). Aarhus: Aarhus University, Denmark. Also available at http://www.tpcloegumkloster.dk/fileadmin/userupload/PDF/E- $\quad$ bog/NCRE2011_E-book $\underline{\text { Oct } 2012}$

3. Asare-Danso, S. (2017). Assessing technological pedagogical content knowledge of religious and moral educators of colleges of education in Ghana: A survey. International Journal of Education and Social Science, 4(11),29-39. www.ijessnet.com

4. Blackmore, K. \& Coosey, B. (1980). A Sociology of Education for Africa. London: George \& Unwin.

5. Bloom, B. (1956). The taxonomy of educational objectives, Handbook I : Cognitive domain. New York: Longman-McKay.

6. Boateng, F. (1983). African traditional Education: A method of disseminating cultural values, In Journal of Black Studies.3, 321-336.

7. Data, A. (1984). Education and society: A Sociology of African Education. London: Macmillan.

8. Dinama, B. (2012). The path so far: Introducing moral education in Botswana secondary schools. International Journal of Scientific Research in Education. 5(2), 100-108.

9. M.O.E. (1964). Education Report on Presbyterian Boys'Secondary School, Legon.

10. National Council for Tertiary Education (N.C.T.E.) (2015). Harmonised Statutes for Colleges of Education.

11. Fafunwa, A. B. (1974). History of Education in Nigeria. London: Allen \& Unwin.

12. Gilligan, C. (1982). In a different voice: Psychological theory and women's development. Harvard University Press: Cambridge.

13. Graham, C. K. (1976). The history of Education in Ghana. Tema: Ghana Publishing Corporation.

14. Gurney, E. (2007). Pastoral letter on Educational Reform: GES damns Bishops, In Daily Graphic. Tuesday, November 20, Issue No. 150209, pp. 1\&3. 
15. Higgins, A., \& Kohlberg, L. (1989). Lawrence Kohlberg's approach to moral education. New York: Columbia University Press.

16. Kalusa, W. T. (2000). Indigenous Education in pre-colonial Africa, In H. T. Msango, E. C. Mumba, \& A. L. Sikwbele, Selected topics in Philosophy and Education. Lusaka: University of Zambia.

17. Katola, M. T. (2014). Incorporation of traditional African cultural values in the formal education system for development, peace building and good governance. European Journal of Research in Social Sciences. 2(3, 31-39.

18. Kohlberg, L. \& Turiel, E. (1971). Moral development and moral education. In G. S. Lesser, ed. Psychology and Educational practice. Scott Foresman.

19. Kohlberg, L. (1969). Stage and sequence: The cognitive developmental approach to socialization. In D. A. Goslin (Ed.), Handbook of socialization theory and research. Chicago: Rand McNally.

20. Kohlberg, L. \& Mayer, R. (1972). Development as the aim of education. Harvard Educational Review, 42(4), 449-496.

21. Mbiti, J. S. (1969). African Religions and Philosophy. New York: Anchor Books.

22. McWilliam, H. O. A. \& Kwamena-Poh,M. A. (1975). The development of Education in Ghana. London: Longman.

23. Meeting the Challenges of the Twenty-First Century. Report of the President's Committee on Review of Education Reforms in Ghana. Executive Summary, (October 2002).

24. Ministry of Education, Science and Sports (2008). Teaching Syllabus for Religious and Moral Education (Junior High School 1-3). Accra: Curriculum Research and Development Division (CRDD)

25. Ministry of Education (1957). Education Report, Ghana.

26. Minutes of the Synod Committee Meeting, Presbyterian Church of Ghana, 25 - 26 April, 1962.

27. Nduka, O. (1980). Moral Education in the changing traditional societies of Sub-Saharan Africa. International Review of Education. 9(2), 130-133.

28. Njoroge, M. (2012). Moral Education in Schools: Is it a worthy undertaking? Paper presented during the $1^{\text {st }}$ Annual International Interdisciplinary Conference, held at Catholic University of Eastern Africa (CUEA), June 27-31.

29. Nyabul, P. (2009). Moral Education and the condition of Africa. Thought ad Practice: A Journal of Philosophical Association of Kenya. 1(1), 31-42.

30. Ocitti, P. (1973). African indigenous education. Nairobi: East African Literature Bureau.

31. Odamtten, S. K. (1978). The missionary factor in Ghana's development (1820-1880). Accra: Waterville Publishing House.

32. Okoro, K. N. (2010). African traditional education: A viable alternative for peace building process in modern Africa. Journal of Alternative Perspectives in the Social Sciences. 2(1), 136-159.

33. Ozigi, A. \& Canham, P. (1979). An introduction to the foundations of education. London: Macmillan.

34. Piaget, J. (1965). The moral judgment of the child. (M. Gabain, Trans.). New York: The Free Press (Original work published 1932).

35. Power, F. C., Higgins, A. \& Kohlberg, L. (1989). Lawrence Kohlberg's approach to moral education. New York: Columbia University Press.

36. PRAAD (1961). Ghana Young Pioneers. Cape Coast PRAAD, 23/1/1560. $31^{\text {st } J a n u a r y ~} 1961$.

37. Smetana, J. G. (1996). Parenting and the development of social knowledge reconceptualized: A social domain analysis. In J.E. Grusec \& L. Kuczynski (Eds.), Handbook of parenting and the transmission of values. New York: Wiley.

38. Turiel, E. (1983). The development of social knowledge: Morality \& convention. New York: Cambridge University Press.

39. Raths, L. E., Harmon, M. \& Simon, S. B. (1966). Values and teaching. Columbus, Ohio: Charles E. Merrill Books, Inc.

40. Wise, C. G. (1956). A history of education in British West Africa. London: Longmans, Green \& Co.

41. Wynne, E. \& Ryan, K. (1993). Reclaiming our schools. New York: Merrill. 